\title{
Study of Adaptation of the Preschool Anxiety's Scale in Children to Turkish
}

\author{
Șahin Hakan ${ }^{1}$ \\ ${ }^{1}$ Department of Preschool Education, Hasan Ali Yucel Faculty of Edication, Istanbul University-Cerrahpasa, \\ Istanbul, Turkey \\ Correspondence: Şahin Hakan, Hasan Ali Yucel Faculty of Education, Istanbul University-Cerrahpasa, Istanbul, \\ Turkey. E-mail: hakansahin@istanbul.edu.tr
}

Received: May 25, 2020

doi:10.5539/ies.v13n9p82
Accepted: June 28, $2020 \quad$ Online Published: August 26, 2020

URL: https://doi.org/10.5539/ies.v13n9p82

\begin{abstract}
The purpose of this research is to study the validity and reliability of the Preschool Anxiety's Scale in a wide Turkish sample according to the age group of 3, 4 and 5 years. 302 of the 918 children participated in the research aged 3 years, 303 are in the age group of 4 and 313 are in the age group of 5. The scale is based on parent's assessment for preschool children aged 3-5 years, the descriptive method was used in the study. During the development process of the scale, 6 experts were consulted for the form that provided the language equality. The Construct validity was also determined based on AFA and DFA. The Corrected item-total correlations and Cronba's Alpha reliability coefficient were calculated in order to determine the reliability of the scale. The KMO and the Barlett test have showed that the factor analysis is suitable for the data set. Within the context of confirmatory factor analysis 28 items and 5 dimensions including in the Anxiety Scale for Preschool Children have been verified with the data obtained in the scope of the research. In accordance with the data obtained from the parents of children aged 3, 4 and 5 years it was determined that the general anxiety, social anxiety, fear of social injury, separation anxiety, the sub-dimensions of the obsessive compulsive disorder and the score obtained from the scale were reliable. The Reliability levels of the overall scale and the sub-factors were found to be sufficient. The scale was found to be reliable and valid by the results acquired in the research. At the end of the study it was found that the scale has the characteristics of being used independently in each group.
\end{abstract}

Keywords: preschool, anxiety, social anxiety, child, children

\section{Introduction}

Anxiety disorders are among the most common childhood psychiatric disorders. The prevalence in Pre-school period is estimated between $2.5 \%$ and $10 \%$ (Rapee, Schniering, \& Hudson, 2009; Egger \& Angold, 2006). There are findings prove that this rate reaches $20 \%$ until the age of 16 (Costello, Mustillo, Erkanli, Keeler, \& Angold, 2003). Anxiety is known to be associated with continuity of many disorders throughout life (Rapee et al., 2009). While some fear and anxiety conditions are normal for children at an early age (Muris \& Rachman, 2007), some anxiety problems continue stably until childhood, adolescence and even adulthood (Costello et al., 2003). Over the past 30 years, a lot of study has been done on the anxiety of older children and adults and many topics have been covered in this area. However, research on anxiety in young kids comes out to be very limited (Edwards, Rapee, Kennedy, \& Spence, 2010).

Study related to anxiety in mid childhood and adolescent has shown the necessity of anxiety to be examined at an early age. Children may show symptoms like anxiety based on different developmental and behavioral disabilities in early years. For example biological-based characteristic features such as unusual shyness, shows at high levels especially at age 6 and 7 (Seven \& Akif-İnci, 2016) cause reactions such as fear and withdraw in new and unknown situations. However, evidence was found that anxiety problems in older children are a reflection of their early ages (Broeren \& Muris, 2008).

Anxiety is not independent of developmental qualities and age characteristics. It should be taken into account especially that emotions develop mostly in the first three years (Seven, 2008). For this reason, it is very difficult to present general symptoms as are in adults (Mian, Godoy, Briggs-Gowan, \& Carter, 2012). Evaluations based on parental reports were made to determine anxiety in early age. In this context, evidence relating to anxiety symptoms in children aged 1-2 years was found (Egger \& Angold, 2006). Spence, Rapee, McDonald, and Ingram 
(2001) determined that children who are 3-year-olds are significantly worried than those aged 4 or 5 years. At the same time, it was reported that anxiety symptoms in preschool and primary school are related to depression and externalization problems during adolescence (Bittner et al., 2007).

It was emphasized that there are clear symptoms of anxiety in preschool years and it is important to recognize anxious children in the early years (Hirshfeld-Becker \& Biederman, 2002). Early diagnosis will be an important opportunity to identify those who meet the criteria of anxiety disorder as well as those who are at risk. Thus, it was reported that risk can be reduced by early prevention and intervention programs (Broeren \& Muris, 2008). It is appeared that in order to make these determinations scales with wide screening qualities are needed in preschool period. For this purpose, there are scales filled by parents. The Child Behavior Assessment Scale (Achenbach, 1991) and the strengths and Difficulties Questionnaire (Goodman, 1997) are some of these. In the meantime beside these scales, some scales were developed to measure the anxiety in preschool period. Children's Moods, Fears and Worries Questionnaire (Bayer, Sanson, \& Hemphill, 2006) and Koala Fear Questionnaire (Muris, Meesters, \& Van Den Berg, 2003) are some of these.

Spence et al. (2001) expressed that children aged 3 years have significantly more anxiety levels than children aged 4 and 5 years. This situation makes it necessary to conduct the validity and reliability study of the Preschool anxiety scale of 3-4 and 5 years old in separate samples. Preschool anxiety scale in Turkey (Türkiye'de Okul öncesi Kaygı ölçeği) was translated into Turkish by Demiray, Mutluer, and Çoskun (2018). Turkish version of a modified form of the Preschool Anxiety Scale was made by Güler (2016). It is shown in both studies that the distribution of the sample by age groups is uncertain.

When reviewing the literature in Turkey (Güler, 2016; Uğraş et al., 2018), there are two scales for measuring the anxiety of preschoolers. However, it is appeared that the features of these scales did not have the validity and reliability studies according especially to the age groups of 3, 4 and 5 in pre-school period. A new study is needed due to changes of the anxiety characteristics by age related to anxiety (Spence et al., 2001).

It was aimed in this research to adapt the parent form of Anxiety Scale in Preschool Children developed by Spence, Rapee, McDonald, and Ingram (2001) to Turkish, in a wide Turkish sample according to the age groups, in a valid and reliable way. The stages of the adaptation process were followed and the results were examined accordingly.

\section{Method}

The purpose of this research was to adapt the Anxiety Scale in Preschool Children developed by Spencer and other (2001) to Turkish in a valid and reliable way. Accordingly, a descriptive research was conducted. The research is in a descriptive survey model. The descriptive method is summarized the topic as is it in the research studies (Büyüköztürk et al., 2017). This model is commonly used in education (Cohen, Manion, \& Morrison, 2017). The purpose in the survey models is to describe a situation in the current as is it in the past. In this study, a descriptive survey model was applied to develop the Anxiety Scale in Preschool Children.

\subsection{Study Group}

During the adaptation of the scale to Turkish, in 2018 a total of 954 children attending public and private preschool institutions were reached in Ankara. Examinations were made according to the answers obtained from the parents of the children. Observations showing missing data and extreme values were excluded from the research. The study was conducted with the data of 918 student accordingly. The distribution of children in the research according to age groups is shown in table1.

Table 1. Cronbach Alpha internal consistency coefficients

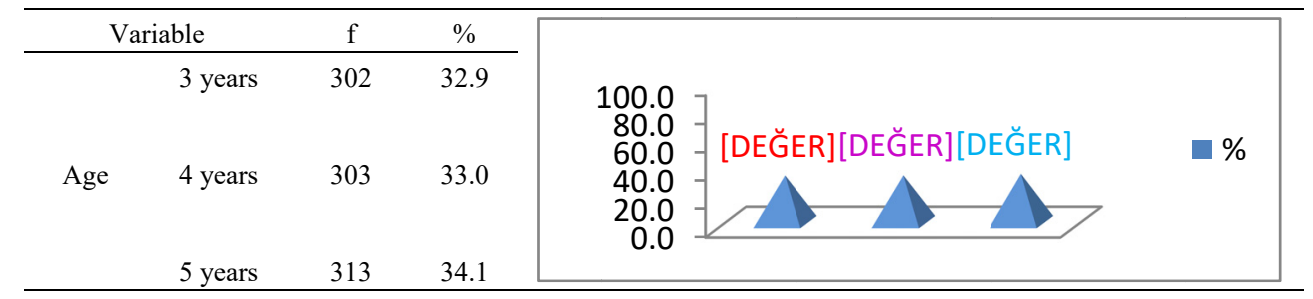

As showing in Table1, children participating in the research $32.9 \%(n=302) 3$ years; $33.0 \%(n=303) 4$ years, $34.1 \%$ $(\mathrm{n}=313)$ are in the age group of 5 . Children show similarities in terms of their ages.

Children in the study group 50.7\% $(n=465)$, attend official independent kindergarten, $25.8 \%(n=237)$ primary 
and secondary school kindergarten $23.5 \%(\mathrm{n}=216)$ attended private kindergarten. $46.7 \%(\mathrm{n}=429)$ of the children are girls and $53.3 \%(\mathrm{n}=489)$ are boys. Mother of $84.1 \%(\mathrm{n}=772)$ of the children participating in the study group and the father of $15.9 \%(n=146)$ answered the scale. $13.4 \%(n=123)$ father of the children in the research group was primary school, father of $38.2 \%(\mathrm{n}=351)$ secondary school, father of $9.9 \%(\mathrm{n}=91)$ high school, father of $(\mathrm{n}=$ 285) $31.0 \%$ associate degree and father of $7.4 \%(n=68)$ is a university graduate. $14.6 \%(n=134)$ mother of the children in the research, primary education, mother of $39.9 \%(\mathrm{n}=366)$ secondary school, mother of $11.7 \%(\mathrm{n}=$ 107) high school graduate, mother of $29.6 \%(\mathrm{n}=272)$ associate degree, $4.2 \%$ mother $(\mathrm{n}=39)$ university graduate. When the distribution of children is examined in terms of income levels $8.8 \%$ of children $(\mathrm{n}=81)$ have monthly income of 1500 TL and below, 38.5\% $(\mathrm{n}=353) 1501-3000 \mathrm{TL}, 251 \%(\mathrm{n}=230) 3001-4435 \mathrm{TL}, 23.1 \%(\mathrm{n}=212)$ 4436-8000 TL, and 4.6\% $(\mathrm{n}=42)$ monthly income was determined to be over 8000 TL. $87.5 \%(\mathrm{n}=803)$ of children live in nuclear family structure, $10.2 \%(\mathrm{n}=94)$ of extended family, and it was determined that $2.3 \%(\mathrm{n}=$ 21) live alone with their mother or father. Children included in the research were heterogeneous in terms of many features; study was not conducted with data from a single school or gender.

\subsection{Data Collection Tool}

In order to determine the anxiety condition in preschool children a measurement tool consisting of a total of 28 items rated as 5-point Likert type was developed by Spence and others. In the development process of the scale, Spence and others, they arranged the 113 items consisting in the Child Behavior List which is answered as "right-part right-not-right". The items were sent to mothers and fathers of children attending preschool between the ages of 3 and 5 after receiving a letter of consent. First, they calculated the exploratory factor analysis based on parent's answers to their children. In the first analysis, it was determined that 28 items were collected in 5 dimensions and clarified $51 \%$ of the total variance. However, in the fifth dimensional model, they found that the dimensions which called general anxiety and social anxiety sub-dimension showed a high correlation among themselves. For this reason, items of social anxiety were removed and the analysis was renewed. It was determined that the items which were collected in four dimensions explained $46.8 \%$ of the total variance and the factor loading values of the 26 items were above 0.40 .

Confirmatory factor analysis was done later in the development of the scale. In this process, it was aimed to determine in which model of the scale reaches the best factor structure by conducting confirmatory factor analysis for four different models. It was revealed at the end of the Confirmatory factor analysis that the best scale structure was obtained from the five-factor model. The factor loading values of the five items in the general anxiety dimension which name the first factor varies between 0.59 and 0.75 , factor loading values of the social anxiety items differs between 0.46 and 0.72 ; factor loading values of the five items consisting in obsessive compulsive disorder dimension was between 0.49 and 0.66 , factor loading values of the seven items consisting in fear of physical injury differ between 0.41 and 0.60 and the factor loading values of the five items including in separation anxiety dimension differs between 0.52 to 0.64 (Spence et al., 2001).

Accordingly, the Anxiety Scale in Preschool Children was set as a scale which collected in five dimensions and has a total of 28 items. All items in the scale are positive in the context of anxiety, in other words no item needs to be recorded. The high scores obtained from the scale show that the children's anxiety is high as well.

\subsection{Adaptation Process of the Scale to Turkish}

The scale's adaptation process to Turkish was followed by the adaptation stages determined by Hambleton and Patsula (1999). First of all, a translation group was created for the scale's instruction and the scale's items. The translation group included three preschool education specialists and a measuring and evaluation specialist. Subsequently, the articles and instructions translated into Turkish were translated again to English with back translation method, and the translations were examined with the original form. Corrections were made on expressions that were found to be inconsistent. After the first corrections were made, the opinions of six preschool experts were taken and necessary changes were made to determine whether the translation items are suitable for Turkish culture (linguistic, semantic and idiomatic context). In order to determine the validity of the structure in the scale adaptation process determined based on the scope validity of expert's opinion, the parents of the preschool children were asked to answer the scale items. Accordingly, the calculations made are included in the findings section.

\subsection{Analysis of the Data}

Within the scope of the research, first of all, 954 children's parents were asked to answer the scale items for their children. When examinations were performed on 954 scales, it was determined that there were large missing values in the data for 28 children and these scales were removed from the data set. Afterwards four data sets were created; including data belong to children of age group 3,4 and 5 and for all the data as well. Extreme value 
analysis was performed in all four data sets, a total of 8 scales showing univariate and multivariate extreme values in each data set were excluded from the data set. Analyzes were conducted with the data of the remaining 918 children. Confirmatory factor analysis (CFA) was performed to determine to what extent the structure in the original of the scale was verified with the data obtained during the scale adaptation process. CFA; it is a technique that analyzes the measurement model in which the number of factors and the indicators related to the factors are predetermined and it is also used to test the accuracy of the previously determined factor structure (Kline, 2011). Because it is a multivariate statistical method, the assumptions of the analysis were examined before the calculation. Firstly, to see whether the data set shows a normal distribution, the skewness-kurtosis coefficients and histogram graphics were examined. The results are shown in Table 2 and Figure 1.

Table 2. Calculated skewness-kurtosis coefficients related to the data sets.

\begin{tabular}{cccc}
\hline Data Sets & $\mathrm{N}$ & Skewness & Stickiness \\
\hline All Data & 918 & 0.817 & 0.603 \\
3 years & 302 & 0.778 & 0.077 \\
4 years & 303 & 0.910 & 0.613 \\
5 years & 313 & 0.848 & 0.453 \\
\hline
\end{tabular}
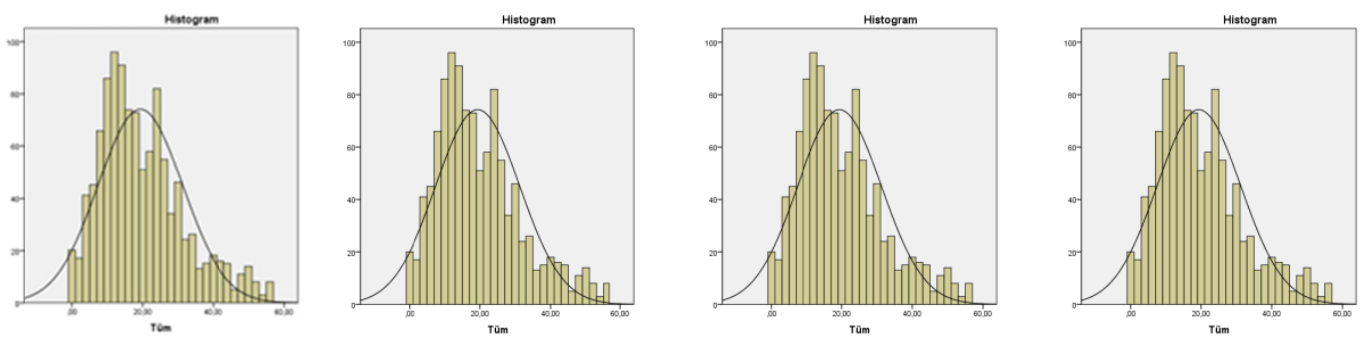

Figure 1. Histogram graphics created for the distribution related to the data sets

When information in Table 2 and Figure 1 were examined, it was found that the observations remaining in the data sets did not deviate excessively from the normal distribution after the missing value and extreme value examination. To determine whether there are multiple connection problems, Correlation between the items was calculated and it was determined that there was no pair item in each data set with a correlation value over 0.80 . Confirmatory factor analysis was done in this context and because the assumptions were provided in the calculation likelihood method was used at most. The analysis was done separately for all data and for each age group. To determine the reliability of the results, the Cronbach's alpha reliability coefficient and the corrected item-total correlation coefficient were calculated. In addition, Pearson correlation coefficient was calculated to determine the relationship between the scale dimensions.

\section{Findings}

In order to determine the structural validity of the scale in the process of adapting the Anxiety Scale in Preschool Children to Turkish. In other words, to determine whether the five-factor structure in the original scale is suitable for Turkish culture, confirmatory factor analysis (CFA) was performed with the data of all the children $(n=918)$. As a result of the verification of the first level CFA, the second level CFA was performed. 


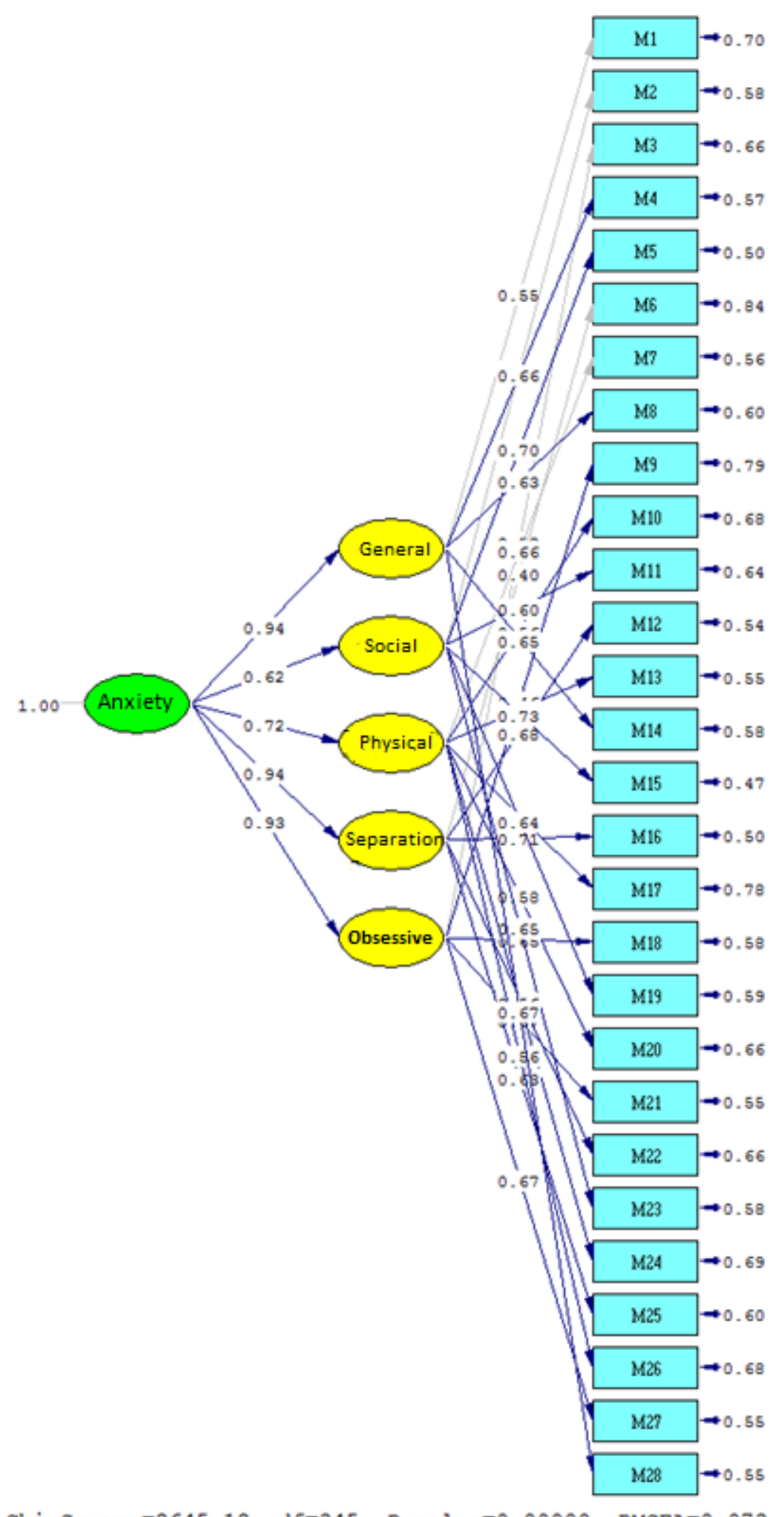

Chi-Square $=2645.12, d f=345, p-$ value $=0.00000$, RMSEA $=0.073$

The path diagram created as a result of the analysis is shown in Figure 2.

Figure 2. Path diagram created as a result of the CFA - standardized coefficients $(n=918)$

The factor loading value, standardized regression coefficient and $t$ values calculated as a result of the confirmatory factor analysis are presented in Table 3 . 
Table 3. Coefficients of anxiety scale in preschool children calculated as a result of the CFA $(n=918)$

\begin{tabular}{|c|c|c|c|c|}
\hline Dimensions & Items & Standardized factor loadings $(\lambda)$ & Regression values $\left(\mathrm{R}^{2}\right)$ & $\mathrm{t}$ values \\
\hline \multirow{5}{*}{ General anxiety } & i1 & 0.55 & 0.30 & --- \\
\hline & i4 & 0.66 & 0.43 & 16.05 \\
\hline & i8 & 0.63 & 0.40 & 15.65 \\
\hline & i14 & 0.65 & 0.42 & 15.90 \\
\hline & i28 & 0.67 & 0.45 & 16.30 \\
\hline \multirow{6}{*}{ Social anxiety } & i2 & 0.65 & 0.42 & --- \\
\hline & i5 & 0.70 & 0.50 & 19.15 \\
\hline & i11 & 0.60 & 0.36 & 16.91 \\
\hline & i15 & 0.73 & 0.53 & 19.64 \\
\hline & i19 & 0.64 & 0.41 & 17.75 \\
\hline & $\mathrm{i} 23$ & 0.65 & 0.42 & 17.88 \\
\hline \multirow{7}{*}{ Fear of phsycal injury } & i7 & 0.66 & 0.44 & --- \\
\hline & $\mathrm{i} 10$ & 0.56 & 0.32 & 15.90 \\
\hline & i13 & 0.67 & 0.45 & 18.28 \\
\hline & i17 & 0.47 & 0.22 & 13.49 \\
\hline & $\mathrm{i} 20$ & 0.58 & 0.34 & 16.37 \\
\hline & i24 & 0.56 & 0.31 & 15.77 \\
\hline & i26 & 0.56 & 0.32 & 15.83 \\
\hline \multirow{5}{*}{ Anxiety of separation } & i6 & 0.40 & 0.16 & --- \\
\hline & $\mathrm{i} 12$ & 0.68 & 0.46 & 11.99 \\
\hline & i16 & 0.71 & 0.50 & 12.13 \\
\hline & $\mathrm{i} 22$ & 0.59 & 0.34 & 11.36 \\
\hline & i 25 & 0.63 & 0.40 & 11.70 \\
\hline \multirow{5}{*}{ Obsessive compulsive disorder } & i3 & 0.58 & 0.34 & --- \\
\hline & i9 & 0.46 & 0.21 & 12.74 \\
\hline & i18 & 0.65 & 0.42 & 16.52 \\
\hline & i21 & 0.67 & 0.45 & 16.93 \\
\hline & i27 & 0.67 & 0.45 & 17.01 \\
\hline
\end{tabular}

As showing in Table 3, the standardized factor loading values of the items in the scale vary between 0.40 and 0.73 . However, it was determined that the factor loading values of the items in the general anxiety dimension vary between 0.40 and 0.71 ; factor loading of the social anxiety items ranged from 0.60 to 0.73 ; the factor loading values of the items of fear of physical injury are between 0.47 and 0.67 . The factor loading values of the items of separation anxiety vary between 0.40 and 0.71 ; the factor loading values of the items in the obsessive compulsive disorder dimension also differ between 0.46 and 0.67 .

When Table 3 is examined, it is shown that the regression coefficients (R2) of the items in the adapted anxiety scale vary between 0.16 and 0.53 . The calculated $t$ values for each item were also found significant $(p<0.05)$. It was also that the general anxiety dimension of the calculated regression coefficients vary between 0.30 and 0.45 , between 0.36 and 0.53 in the dimension of the social anxiety; between 0.22 and 0.45 in the dimension of the fear of physical injury, between 0.16 and 0.50 in the dimension of the fear of separation anxiety; and between 0.21 and 0.45 in the dimension of the obsessive compulsive.

Standardized factor loadings ( $\lambda=$ Lambda) give an idea about how much variation a unit change in the latent variable will cause in the observed variable, in other words, the relationship between the observed variable and the corresponding latent variable. If the values are high, this indicates a strong relation between the latent and the observed variable (Çokluk, Şekercioğlu, \& Büyüköztürk, 2010). As showing in Table 3, the standardized factor loading values of the items in the scale vary between 0.40 and 0.73 . In other words, all the items are in medium or high level relationship with the latent variable. The factor loadings values of the items in general anxiety dimension are between 0.40 and 0.71 . Factor loadings of social anxiety items are between 0.60 and 0.73 ; the loadings values of fear of physical injury items are between 0.47 and 0.67 . The factor loadings values of separation anxiety items are between 0.40 and 0.71 ; the factor loadings values of the obsessive compulsive disorder items were also found to differ between 0.46 and 0.67 . 
The standardized regression coefficients (R2) values show how much the explained variance in the observed variable is due to the latent variable (Çokluk et al., 2010). When examine table 4, it is showed that the regression coefficients of the items of the adapted anxiety scale vary between 0.16 and 0.53 . The fact that the $t$ values calculated for each item are also significant $(\mathrm{p}<0.05)$ shows that all the items in the scale are a significant explanatory of the dimension to which they belong. The calculated regression coefficients differ between 0.30 and 0.45 in the general anxiety dimension, between 0.36 and 0.53 in the dimension of social anxiety, between 0.22 and 0.45 in the dimension of fear of physical injury, between 0.16 and 0.50 in the dimension of separation anxiety; and it was also determined that there was a difference between 0.21 and 0.45 in the obsessive compulsive disorder dimension. During the calculation the CFA model, it was determined that the dimension to which all the items belong provided a significant explanatory and linearity assumption. Afterward, the structural equations in the second level of CFA were examined. The coefficients calculated in the context of structural equations are shown in Table 4.

Table 4. Structural coefficients of the Anxiety Scale in Preschool Children calculated as a result of the CFA ( $\mathrm{n}=$ 918)

\begin{tabular}{ccccc}
\hline Sub dimensions & Explained variable & $\beta$ & $\mathrm{R}^{2}$ & $\mathrm{t}$ \\
\hline General anxiety & & 0.94 & 0.88 & 17.90 \\
Social anxiety & & 0.62 & 0.38 & 15.79 \\
Fear of physical injury & Anxiety & 0.72 & 0.51 & 17.76 \\
Separation anxiety & & 0.94 & 0.88 & 12.53 \\
Obsessive compulsive disorder & & 0.93 & 0.87 & 18.88 \\
\hline
\end{tabular}

When information in Table 4 is examined, it was determined that the general anxiety of the anxiety levels of preschool children $(\mathrm{R} 2=0.88 ; \mathrm{p}<0.05)$, social anxiety $(\mathrm{R} 2=0.38 ; \mathrm{p}<0.05)$, fear of physical injury $(\mathrm{R} 2=0.51$; $\mathrm{p}<0.05)$, separation anxiety $(\mathrm{R} 2=0.88 ; \mathrm{p}<0.05)$ and obsessive compulsive disorder $(\mathrm{R} 2=0.87 ; \mathrm{p}<0.05)$ were explained by the sub-dimensions in a meaningful way. After the calculation phase of the model, the model-data fitting analysis was started. The criteria and the values acquired from the model are shown Table 5.

Table 5. Adaptation indices calculated as a result of the CFA related to anxiety scale in preschool children $(\mathrm{n}=918)$

\begin{tabular}{cccc}
\hline Compliance criteria & Perfect harmony & Acceptable harmony & Anxiety scale values \\
\hline $\mathrm{X}^{2} / \mathrm{sd}$ & $0 \leq \mathrm{X}^{2} / \mathrm{sd} \leq 4$ & $0 \leq \mathrm{X}^{2} / \mathrm{sd} \leq 5$ & 7.67 \\
$\mathrm{RMSEA}$ & $0 \leq \mathrm{RMSEA} \leq .05$ & $.05<\mathrm{RMSEA} \leq .08$ & 0.073 \\
$\mathrm{NFI}$ & $.95 \leq \mathrm{NFI} \leq 1.00$ & $.90 \leq \mathrm{NFI}<.95$ & 0.91 \\
$\mathrm{NNFI}$ & $.97 \leq \mathrm{NNFI} \leq 1.00$ & $.95 \leq \mathrm{NNFI}<.97$ & 0.91 \\
$\mathrm{CFI}$ & $.95 \leq \mathrm{CFI} \leq 1.00$ & $.90 \leq \mathrm{CFI}<.95$ & 0.92 \\
GFI & $.95 \leq \mathrm{GFI} \leq 1.00$ & $.90 \leq \mathrm{GFI}<.95$ & 0.92 \\
\hline
\end{tabular}

Source: Schermelleh-Engel, Moosbrugger, and Müller (2003).

When evaluating the values in Table 5, the $\mathrm{X} 2 / \mathrm{sd}$ fitting value is calculated as (7.67). However, RMSEA, NFI, NNFI, CFI and the GFI compliance values were found to be acceptable.

When the values in Table 5 are analyzed, it is shown that the X2/sd compliance value is calculated above the acceptable limit (7.67). According to Sayın and Gelbal's (2016) studies, the X2/sd adjustment value showed a monotonous increase due to increase in the sample size; They determined that the X2/sd fitting value may be misleading, especially when the sample exceeds 500. Since the study was conducted with the data of 918 children, it was normal for $\mathrm{X} 2 / \mathrm{sd}$ to exceed the acceptable values. However, the RMSEA, NFI, NNFI, CFI and GFI compliance values were found to be acceptable. The values calculated in this case showed that the 28 items and the 5 dimensions including in the Anxiety Scale in Preschool has been verified with the data acquired in the research.

\subsection{Reliability Analysis Results}

After the confirmatory factor analysis, the Cronbach's alpha coefficient was calculated in order to determine the reliability of the items with high validity values. The calculation's results are shown in Table 6. 
Table 6. Calculated Cronbach's alpha reliability coefficient related to the anxiety scale in preschool Children ( $\mathrm{n}=$ 918)

\begin{tabular}{cccc}
\hline Sub- dimensions & Number of items & N & Cronbach's alpha \\
\hline General anxiety & 5 & 918 & 0.679 \\
Social anxiety & 6 & 918 & 0.741 \\
Fear of physical injury & 5 & 918 & 0.736 \\
Separation anxiety & 7 & 918 & 0.633 \\
Obsessive compulsive disoder & 5 & 918 & 0.622 \\
Anxiety scale in preschool children & 28 & 918 & 0.877 \\
\hline
\end{tabular}

As showing in Table 6, the Cronbach's alpha reliability coefficient of the parents's responses to the items in the Anxiety Scale in Preschool Children was calculated as 0.877. Cronbach's alpha coefficient was calculated as follow 0.679 for the general anxiety dimension, 0.741 for social anxiety dimension, 0.622 for fear of physical injury, 0.736 for separation anxiety and 0.633 for obsessive compulsive disorder. It was determined that the scale is quite reliable when the Cronbach's alpha value is calculated as 0.60 and above (Kalayc1, 2009). Based on this information the results obtained from the scale adapted to Turkish were to be reliable.

\subsection{Items Analysis Results}

The items were corrected according to the opinion of 918 parents who responded to the Anxiety Scale in Preschool Children, the item-total correlation coefficients were calculated and the results are shown in Table 7.

Table 7. Corrected item-total correlation coefficients of items including in the anxiety scale in preschool children $(\mathrm{n}=918)$

\begin{tabular}{|c|c|c|}
\hline Dimensions & Items & Correlation Coefficient \\
\hline \multirow{5}{*}{ General anxiety } & i1 & 0.431 \\
\hline & i4 & 0.526 \\
\hline & i8 & 0.447 \\
\hline & $\mathrm{i} 14$ & 0.367 \\
\hline & i 28 & 0.422 \\
\hline \multirow{6}{*}{ Social anxiety } & $\mathrm{i} 2$ & 0.507 \\
\hline & $\mathrm{i} 5$ & 0.526 \\
\hline & i11 & 0.480 \\
\hline & $\mathrm{i} 15$ & 0.555 \\
\hline & i19 & 0.473 \\
\hline & $\mathrm{i} 23$ & 0.376 \\
\hline \multirow{7}{*}{ Fear of physical injury } & i7 & 0.492 \\
\hline & $\mathrm{i} 10$ & 0.377 \\
\hline & $\mathrm{i} 13$ & 0.512 \\
\hline & $\mathrm{i} 17$ & 0.357 \\
\hline & $\mathrm{i} 20$ & 0.491 \\
\hline & i24 & 0.467 \\
\hline & $\mathrm{i} 26$ & 0.450 \\
\hline \multirow{5}{*}{ Separation anxiety } & i6 & 0.373 \\
\hline & $\mathrm{i} 12$ & 0.486 \\
\hline & i16 & 0.514 \\
\hline & $\mathrm{i} 22$ & 0.351 \\
\hline & $\mathrm{i} 25$ & 0.397 \\
\hline \multirow{5}{*}{ Obsesssive compulsive disorder } & $\mathrm{i} 3$ & 0.406 \\
\hline & i9 & 0.389 \\
\hline & i18 & 0.479 \\
\hline & $\mathrm{i} 21$ & 0.320 \\
\hline & $\mathrm{i} 27$ & 0.344 \\
\hline
\end{tabular}


When the information in Table 7 is examined, it is shown that the corrected item-total correlation coefficients of the items in the scale vary between 0.320 and 0.555 . Items of general anxiety between 0.367 and 0.526 ; items in social anxiety dimension between 0.473 and 0.555 ; items in fear of physical injury dimension between 0.357 and 0.512 ; items in separation anxiety dimension between 0.351 and 0.514 ; items in obsessive compulsive disorder dimension between 0.320 and 0.479 . It was determined that the item-total correlation coefficients vary. In other words, all the items in the scale have intermediate and high level of clarity (Tabachnick \& Fidell, 2012).

\subsection{Correlation Analysis Between the Dimensions}

In order to calculate the relationships among the sub-dimensions in the scale related to the answers obtained from the parents who responded to the Anxiety Scale in Preschool Children Pearson's correlation coefficient was calculated. The results are shown in Table 8.

Table 8. Relationships among the anxiety scale sub-dimensions in preschool children $(\mathrm{n}=918)$

\begin{tabular}{|c|c|c|c|c|c|c|c|}
\hline Sub-dimensions & Values & $\begin{array}{l}\text { General } \\
\text { anxiety }\end{array}$ & $\begin{array}{l}\text { Social } \\
\text { anxiety }\end{array}$ & $\begin{array}{c}\text { Obsessive compulsive } \\
\text { disorder }\end{array}$ & $\begin{array}{c}\text { Fear of physical } \\
\text { injury }\end{array}$ & $\begin{array}{c}\text { Separation } \\
\text { anxiety }\end{array}$ & $\begin{array}{c}\text { Total } \\
\text { anxiety }\end{array}$ \\
\hline \multirow{3}{*}{ General anxiety } & $\mathrm{r}$ & 1 & 0.503 & 0.504 & 0.457 & 0.573 & 0.769 \\
\hline & $\mathrm{p}$ & & 0.000 & 0.000 & 0.000 & 0.000 & 0.000 \\
\hline & $\mathrm{N}$ & 918 & 918 & 918 & 918 & 918 & 918 \\
\hline \multirow{3}{*}{ Social anxiety } & $\mathrm{r}$ & 0.503 & 1 & 0.330 & 0.349 & 0.423 & 0.686 \\
\hline & $\mathrm{p}$ & 0.000 & & 0.000 & 0.000 & 0.000 & 0.000 \\
\hline & $\mathrm{N}$ & 918 & 918 & 918 & 918 & 918 & 918 \\
\hline \multirow{3}{*}{$\begin{array}{c}\text { Obsessive compulsive } \\
\text { disorder }\end{array}$} & $\mathrm{r}$ & 0.504 & 0.330 & 1 & 0.448 & 0.573 & 0.732 \\
\hline & $\mathrm{p}$ & 0.000 & 0.000 & & 0.000 & 0.000 & 0.000 \\
\hline & $\mathrm{N}$ & 918 & 918 & 918 & 918 & 918 & 918 \\
\hline \multirow{3}{*}{ Fear of physical injury } & $\mathrm{r}$ & 0.457 & 0.349 & 0.448 & 1 & 0.518 & 0.784 \\
\hline & $\mathrm{p}$ & 0.000 & 0.000 & 0.000 & & 0.000 & 0.000 \\
\hline & $\mathrm{N}$ & 918 & 918 & 918 & 918 & 918 & 918 \\
\hline \multirow{3}{*}{ Separation anxiety } & $r$ & 0.573 & 0.423 & 0.573 & 0.518 & 1 & 0.803 \\
\hline & $\mathrm{p}$ & 0.000 & 0.000 & 0.000 & 0.000 & & 0.000 \\
\hline & $\mathrm{N}$ & 918 & 918 & 918 & 918 & 918 & 918 \\
\hline \multirow{3}{*}{ Total anxiety } & $\mathrm{r}$ & 0.769 & 0.686 & 0.732 & 0.784 & 0.803 & 1 \\
\hline & $\mathrm{p}$ & 0.000 & 0.000 & 0.000 & 0.000 & 0.000 & \\
\hline & $\mathrm{N}$ & 918 & 918 & 918 & 918 & 918 & 918 \\
\hline
\end{tabular}

As showing in Table 8, it was determined was positive and high levels relationships between anxiety dimensions and the general anxiety $(\mathrm{r}=0.769 ; \mathrm{p}<0.01)$, social anxiety $(\mathrm{r}=0.686 ; \mathrm{p}<0.01)$, obsessive compulsive disorder $(\mathrm{r}=$ $0.732 ; \mathrm{p}<0.01)$, fear of physical injury $(\mathrm{r}=0.784 ; \mathrm{p}<0.01)$, and the separation anxiety $(\mathrm{r}=0.803 ; \mathrm{p}<0.01)$. In other words, each sub-dimension in the scale is related to the children's anxiety. It was determined that the general anxiety and social anxiety dimensions were highly related in the development process of the scale; however, since the best results for the construct validity give a five-dimensional model with two related dimensions, they accepted that structure (Spence and others 2001). It was also shown that there was a positive and moderate relationship between the general anxiety and social anxiety in the scale adapted to Turkish $(r=0.503 ; p<0.01)$. In other words, the high relationship (multiple connections) between the dimensions in the original of the scale was not observed as a result of adaptation.

\subsection{Confirmatory Factor Analysis Results Calculated for the Preschool Children According to Their Ages}

It was determined that the Anxiety Scale in Preschool Children which was adapted to Turkish with answers obtained from the parents of children aged 3-5 years was conducted in a valid in a reliable way. Although, the 28 items including in the scale and the expressions of the items are not long at the same time the scale is also useful. In order to determine whether the Anxiety Scale in Preschool Children will be used separately in each age group, data of children in the age group of $3(n=302), 4(n=303)$ and $5(n=313)$ three CFA were conducted. Path diagrams created as a result of the CFA are shown in Figure 3. 


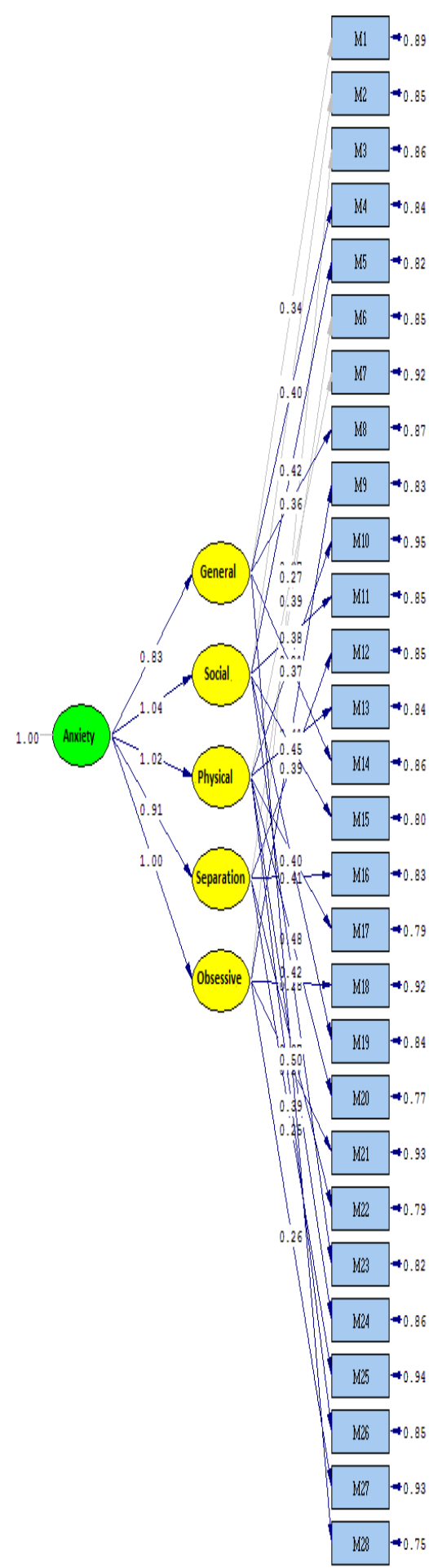

Chi-Square $=544.31, \mathrm{df}=345, \mathrm{P}-\mathrm{value}=0.00000$, RMSEA $=0.038$

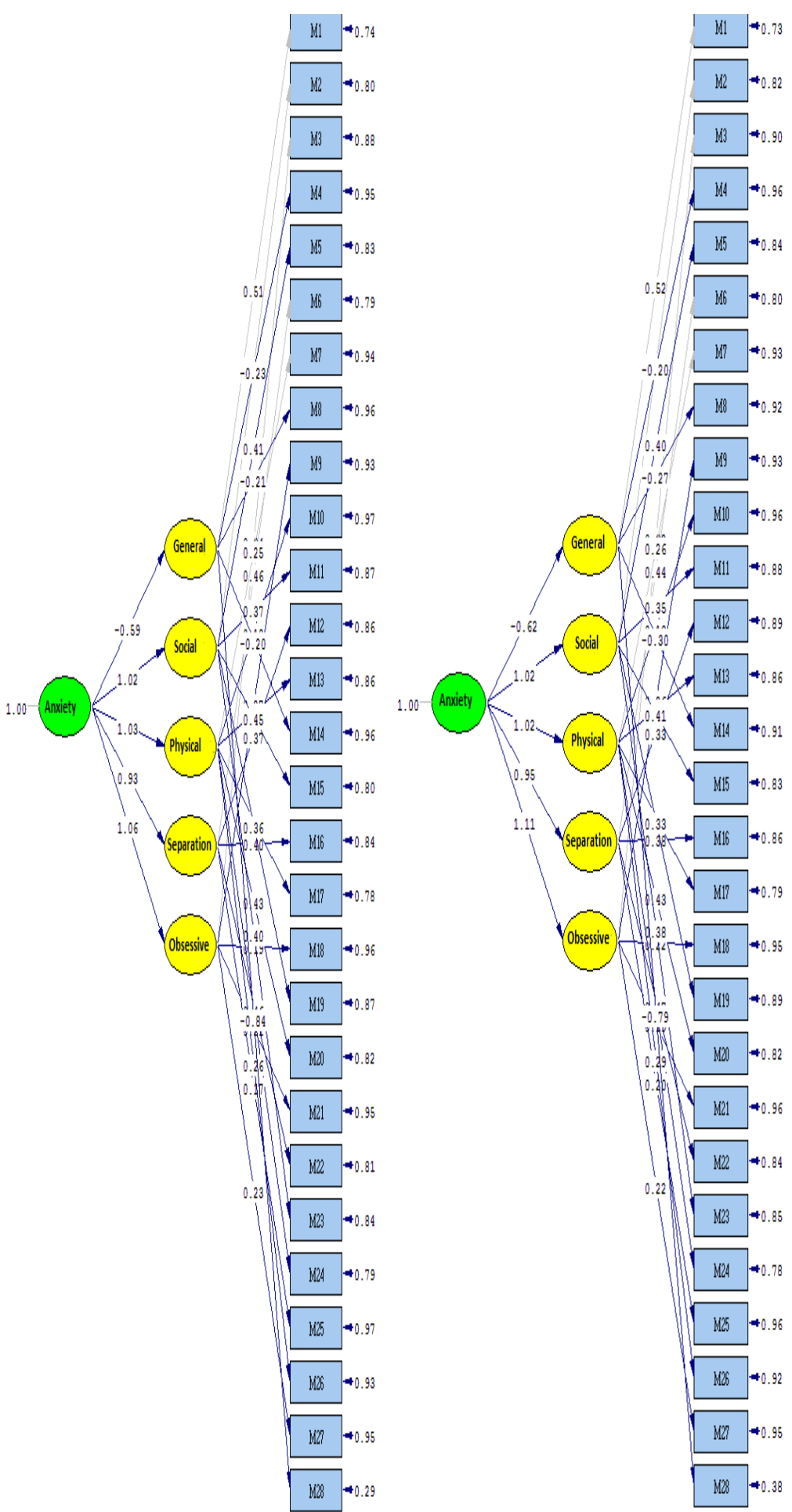

Chi-8quare $=488.25, \mathrm{df}=345, \mathrm{p}-\mathrm{value}=0.00000, \mathrm{RMSEA}=0.037$ Chi-8quare $=683.13, \mathrm{df}=345, \mathrm{p}-\mathrm{value}=0.00000, \mathrm{RMSEA}=0.049$

4 years $(n=303)$

5 years $(n=313)$

Figure 3. Path diagram created as a result of CFA - standardized coefficients

As showing in Figure 3, it was found that the items in the Anxiety Scale in Preschool Children significantly explain the dimensions which they belong to in each age group. Pearson correlation coefficient was calculated to determine the relationships between the coefficients calculated as a result of each analysis, the calculations results are presented in Table 9. 
Table 9. Relationships between the coefficients calculated for each age group as a result of DFA

\begin{tabular}{ccccc}
\hline Data sets & values & $\lambda$ & $\mathrm{R}^{2}$ & $\mathrm{t}$ \\
\hline \multirow{3}{*}{ 3 years-4 years } & $\mathrm{r}$ & 0.699 & 0.654 & 0.712 \\
& $\mathrm{p}$ & 0.000 & 0.000 & 0.000 \\
& $\mathrm{~N}$ & 28 & 28 & 28 \\
\hline \multirow{3}{*}{ 3 years- 5 years } & $\mathrm{r}$ & 0.695 & 0.652 & 0.705 \\
& $\mathrm{p}$ & 0.000 & 0.000 & 0.000 \\
& $\mathrm{~N}$ & 28 & 28 & 28 \\
\hline 4 years-5 years & $\mathrm{r}$ & 0.702 & 0.692 & 0.732 \\
& $\mathrm{p}$ & 0.000 & 0.000 & 0.000 \\
& $\mathrm{~N}$ & 28 & 28 & 28 \\
\hline
\end{tabular}

According to the information in Table 9, it was determined that there was a positive and high level relationship among the factor loading value, regression coefficient and the $t$ value as a result of the answers obtained from the parents of children of each age group. The data fit model indexes calculated with the data of the children in each age group is presented in Table 10 .

Table 10 Calculated fit indices related to the data of the child in each age group and the anxiety scale in preschool children

\begin{tabular}{cccc}
\hline Compliance criteria & 3 years & 4 years & 5 years \\
\hline $\mathrm{X}^{2} / \mathrm{sd}$ & 1.58 & 1.42 & 1.98 \\
$\mathrm{RMSEA}$ & 0.038 & 0.037 & 0.049 \\
$\mathrm{NFI}$ & 0.94 & 0.94 & 0.92 \\
$\mathrm{NNFI}$ & 0.95 & 0.94 & 0.92 \\
$\mathrm{CFI}$ & 0.95 & 0.95 & 0.93 \\
$\mathrm{GFI}$ & 0.91 & 0.90 & 0.91 \\
\hline
\end{tabular}

When Table 10 is analysed, it is found that the data fit model is achieved as a result of CFA calculated for each age group. In other words, the model in the scale was verified separately for each age group. Cronbach's alpha reliability coefficients calculated according to the answers obtained from the parents of each age group are presented in Table 11.

Table 11. Cronbach alpha reliability coefficient calculated for the data of the child in each age group related to the anxiety scale in preschool children $(\mathrm{n}=918)$

\begin{tabular}{cccc}
\hline Sub-dimensions & 3 years & 4 years & 5 years \\
\hline General anxiety & 0.656 & 0.687 & 0.666 \\
Social anxiety & 0.757 & 0.760 & 0.730 \\
Fear of physical injury & 0.701 & 0.667 & 0.675 \\
Separation anxiety & 0.614 & 0.632 & 0.619 \\
Obsessive compulsive disorder & 0.612 & 0.658 & 0.639 \\
Anxiety Scale in Preschool Children & 0.872 & 0.842 & 0.830 \\
\hline
\end{tabular}

When Table 11 is examined, it was determined that the sub-dimensions and the scores obtained from the scale are reliable according to data obtained from the parents of children in the age group of 3,4 and 5 years. Obtained CFA and the reliability analysis results showed that the Anxiety Scale in Preschool Children adapted to Turkish can be used in any age group.

\section{Results and Discussion}

The standardized factor load values of the items in the scale and sub-scales vary between 0.40 and 0.73 . The Standardized factor loading $(\lambda=$ Lambda) give an idea about how much variation a unit change in the latent variable will cause in the observed variable, in other words, the relationship between the observed variable and the latent variable. The fact that these values are high indicates a strong relationship between the latent and observed variable (Çokluk, Şekercioğlu, \& Büyüköztürk, 2010). In other words, all the items are in moderate or 
high level relationship with latent variable.

It is shown that the regression coefficients of the items in the adapted anxiety scale vary between 0.16 and 0.53 the Standardized regression coefficients (R2) values show how much of the explained variance in the observed variable is a result of the latent variable (Çokluk et al., 2010). The fact that the $t$ values calculated for each item were significant $(\mathrm{p}<0.05)$ shows that all the items in the scale are a significant explanatory of the size to which they belong. According to Saylb and Gelbal's (2016) studies, the $\mathrm{X}^{2} / \mathrm{sd}$ fitting value showed a monotonous increase as a result of the increase in the sample size. They determined that the $\mathrm{X}^{2} / \mathrm{sd}$ fitting value may be misleading, especially when the sample exceeds 500. After examination, it is shown that the $\mathrm{X}^{2} / \mathrm{sd}$ fitting value is calculated over the acceptable limit (7.67). Because this study was conducted with the data of 918 children, it is normal that the $\mathrm{X}^{2} / \mathrm{sd}$ to exceed the acceptable values. However, RMSEA, NFI, NNFI, CFI and the GFI compliance values were found to be acceptable. In this case, the calculated values, the 28 items and 5 dimensions consist in the Anxiety Scale in Preschool Children shows that it is verified with the data obtained in the research.

Kalayc1 (2009) states that the scale is quite reliable when the Cronbach's alpha value is calculated as 0.60 and above. In line with these information it is determined that the results obtained from the scale and the sub-factors adapted to Turkish are reliable. The Corrected item-total correlation coefficients of the items in the scale and its sub-dimensions vary between 0.320 and 0.555 . Thus, it was determined that all the items in the scale have moderate and high level of clarification (Tabachnick \& Fidell, 2012).

The purpose of this study was to re-examine the validity and reliability of the Turkish form of the Preschool Anxiety Scale developed by Spence, Rapee, McDonald, and Ingram (2001). The study was conducted with a large sample distributed similarly to each age group. Values calculated within the confirmatory factor analysis the 28 items and 5 dimensions including in the Anxiety Scale in Preschool Children show that it has been verified with the data obtained within the scope of the research. This finding is consistent with the 5 factors of the scale determined by (Spence et al., 2001). These factors are the sub-dimension of the general anxiety; social anxiety, fear of physical injury, separation anxiety and the obsessive compulsive disorder. Result obtained by Spence, Rapee, McDonald, and Ingram (2001) that proved significantly a higher levels of anxiety in children aged 4 and 5 years, it was required to work separately with each age group in this study. The scale that constitutes the most important difference of the study was examined to determine whether it was suitable for every age group and it was determined that the sub-dimensions and the scores obtained from the scale were reliable in accordance with the data obtained from the parents of children in the age group of 3, 4 and 5 years. It showed that the Anxiety Scale in Preschool Children can be used separately for 3, 4 and 5 years old only when one age group is taken. It was determined that each sub-dimension in the scale is related to children's anxiety. Spence and others (2001) determined that the general anxiety and the social anxiety dimensions were highly associated with the development process of the scale however, since the best results for the construct validity were given a five-dimensional model with two related dimensions, they accepted the structure. The high multiple connections between the dimensions including in the original of the scale were not observed as a result of the adaptation.

All the items in the study were found moderately or strongly related to the latent variable. It was determined that all the items in the scale have moderate and high level of clarity (Tabachnick \& Fidell, 2005). The reliability levels of the scale and sub-factors were found to be sufficient. Therefore, the scale was found to be valid and reliable. The determination of the ability to use separately for 3, 4 and 5 years and together for all three age groups in a large sample is the strongest aspect of the study.

However, conditions such as conducting the research only in Ankara province and not calculating the compliance according to gender constitute the limitations of the research. In other to apply the scale to a large sample more studies are needed and in particular it is recommended to address gender factor by age.

\section{References}

Achenbach, T. (1991). Manual for the Teacher's Report Form and 1991 profile. Burlington: Department of Psychiatry, University of Vermont.

Aksoy, M. A. (2010). Öğretmen adaylarının öğretmenlik mesleğine \& ilişkin tutumları (Gaziosmanpaşa üniversitesi örneği). Sosyal Bilimler Araştırmaları Dergisi, 2, 197-212. https://doi.org/10.19129/sbad.177

Bayer, J. K., Sanson, A. V., \& Hemphill, S. A. (2006). Children's moods, fears, and worries: Development of an early childhood parent questionnaire. Journal of Emotional and Behavioral Disorders. https://doi.org/10.1177/10634266060140010401

Bittner, A., Egger, H. L., Erkanli, A., Jane-Costello, E., Foley, D. L., \& Angold, A. (2007). What do childhood 
anxiety disorders predict? Journal of Child Psychology and Psychiatry and Allied Disciplines. https://doi.org/10.1111/j.1469-7610.2007.01812.x

Broeren, S., \& Muris, P. (2008). Psychometric evaluation of two new parent-rating scales for measuring anxiety symptoms in young Dutch children. Journal of Anxiety Disorders. https://doi.org/10.1016/j.janxdis.2007.09.008

Büyüköztürk, Ş., Kılıç-Çakmak, E., Erkan-Akgün, Ö., Karadeniz, Ş., \& Demirel, F. (2017). Bilimsel araştırma yöntemleri. In Bilimsel araştırma yöntemleri. https://doi.org/10.14527/9789944919289

Cohen, L., Manion, L., \& Morrison, K. (2017). Research Methods in Education. https://doi.org/10.4324/9781315456539

Çokluk, Ö., Şekercioğlu, G., \& Büyüköztürk, Ş. (2010). Sosyal bilimler için çok değişkenli istatistik SPSS ve LISREL uygulamaları. Pegem Akademi.

Costello, E. J., Mustillo, S., Erkanli, A., Keeler, G., \& Angold, A. (2003). Prevalence and development of psychiatric disorders in childhood and adolescence. Archives of General Psychiatry. https://doi.org/10.1001/archpsyc.60.8.837

Edwards, S. L., Rapee, R. M., Kennedy, S. J., \& Spence, S. H. (2010). The assessment of anxiety symptoms in preschool-aged children: The revised preschool anxiety scale. Journal of Clinical Child and Adolescent Psychology. https://doi.org/10.1080/15374411003691701

Egger, H. L., \& Angold, A. (2006). Common emotional and behavioral disorders in preschool children: Presentation, nosology, and epidemiology. Journal of Child Psychology Psychiatry, 47(3), 313-337. https://doi.org/10.1111/j.1469-7610.2006.01618.x

Goodman, R. (1997). The strengths and difficulties questionnaire: A research note. Journal of Child Psychology and Psychiatry and Allied Disciplines. https://doi.org/10.1111/j.1469-7610.1997.tb01545.x

Güler, M. (2016). Okul öncesi dönem 4-6 yaşş̧ocukları için yeniden düzenlenen okul öncesi kaygı ölçeğinin geçerlik ve güvenirlik çalışması Adnan Menderes Üniversitesi. https://doi.org/10.16991/INESJOURNAL.1347

Güvenir, T., Özbek, A., Baykara, B., Arkar, H., Şentürk, B., \& İncekaş, S. (2008). Güçler Ve Güçlükler Anketinin (Gga) Türkçe Uyarlamasının Psikometrik Özellikleri. Çocuk ve Gençlik Ruh Sağgl̆ğı Dergisi, 15, 65-74.

Hambleton, R. K., \& Patsula, L. (1999). Increasing the Validity of Adapted Tests: Myths to be Avoided and Guidelines for Improving Test Adaptation Practices. Journal of Applied Testing Technology, 1(1), 1-30. https://doi.org/10.1017/CBO9781107415324.004

Hirshfeld-Becker, D. R., \& Biederman, J. (2002). Rationale and principles for early intervention with young children at risk for anxiety disorders. Clinical Child and Family Psychology Review. https://doi.org/10.1023/A:1019687531040

Kalaycı, Ş. (2009). SPSS Uygulamalı Çok Değişkenli İstatistik Teknikleri. Ankara: Asil Yayın Dağııım.

Kline, R. B. (2011). Principles and practice of structural equation modeling (3rd ed.). In Structural Equation Modeling. https://doi.org/10.1038/156278a0

Mian, N. D., Godoy, L., Briggs-Gowan, M. J., \& Carter, A. S. (2012). Patterns of anxiety symptoms in toddlers and preschool-age children: Evidence of early differentiation. Journal of Anxiety Disorders. https://doi.org/10.1016/j.janxdis.2011.09.006

Muris, P., \& Rachman, S. J. (2007). Normal and Abnormal Fear and Anxiety in Children and Adolescents. https://doi.org/10.1016/B978-0-08-045073-5.X5000-X

Muris, P., Meesters, C., \& Van Den Berg, S. (2003). Internalizing and externalizing problems as correlates of self-reported attachment style and perceived parental rearing in normal adolescents. Journal of Child and Family Studies. https://doi.org/10.1023/A:1022858715598

Rapee, R. M., Schniering, C. A., \& Hudson, J. L. (2009). Anxiety Disorders During Childhood and Adolescence: Origins and Treatment. Annual Review of Clinical Psychology. https://doi.org/10.1146/annurev.clinpsy.032408.153628

Schermelleh-Engel, K., Moosbrugger, H., \& Müller, H. (2003). Evaluating the fit of structural equation models: Tests of significance and descriptive goodness-of-fit measures. MPR-Online, 8(2), 23-74.

Seven, S. (2008). Çocuk ruh sağllğı. Ankara: Pegem Akademi. https://doi.org/10.14527/9786050022094 
Seven, S., \& Akif-İnci, M. (2016). Social Behaviors in Nuclear and Extended families Children Age 6 to 11 - A Longitudinal Study with Turkish Sample. International Journal of Social Science and Humanity. https://doi.org/10.7763/ijssh.2016.v6.623

Spence, S. H., Rapee, R., McDonald, C., \& Ingram, M. (2001). The structure of anxiety symptoms among preschoolers. Behaviour Research and Therapy. https://doi.org/10.1016/S0005-7967(00)00098-X

Tabachnick, B. G., \& Fidell, L. S. (2012). Using multivariate statistics (6th ed.). New York: Harper and Row. https://doi.org/10.1037/022267

Uğraş, S., Demiray, Ç., Mutluer, T., \& Coşkun, M. (2018). Okul Öncesi Çocuklarda Anksiyete Ölçeğinin Türkçe Geçerlik Güvenirlik Çalışması. Çocuk ve Gençlik Ruh Sağllğı Dergisi, 25(1), 63-76.

Yurduşen, S., Erol, N., \& Gençöz, T. (2013). The effects of parental attitudes and mothers' psychological well-being on the emotional and behavioral problems of their preschool children. Maternal and Child Health Journal. https://doi.org/10.1007/s10995-012-0946-6

\section{Copyrights}

Copyright for this article is retained by the author(s), with first publication rights granted to the journal.

This is an open-access article distributed under the terms and conditions of the Creative Commons Attribution license (http://creativecommons.org/licenses/by/4.0/). 